\title{
Enhancing Graduate Employability: Why Higher Education Institutions have problems with teaching generic skills?
}

Okolie, U.C., Igwe, P.A., Eneje, B.C., Nwosu, H., Mlanga, S. (2019), Enhancing graduate employability: Why do higher education institutions have problems with teaching generic skills? Policy Futures in Education, DOI:10.1177/1478210319864824

\begin{abstract}
One debate among business owners and policymakers' centre on whether higher education institutions (HEIs) are failing to transform the young generation by reorienting education to develop higher competencies, skills, values and behaviours. While previous studies have considered the importance of skills development and its assessment in many contexts, there appears to have been limited scholarly research on employability issues within the Higher education system (HES) in Nigeria. In seeking to address this, it is vital to understand how HEIs in Nigeria conceptualize generic skills and why HEIs have problems with teaching generic skills in its graduate programmes. By adopting a qualitative approach, based on interviews with senior academics, industry executives and final year undergraduates, this study finds that many of HEIs do not facilitate the teaching of high-level generic skills in their programmes. Some of the factors attributed to this include poor learning environment, lack of staff with industry experience and over-dependence on 'theoretical content' teaching. The findings are significant for re-orienting HE curriculum to align with the needs of the industry and society. Regarding, implications for policy, we recommend that enterprise education be mandatory in the curriculum for primary, secondary and tertiary education in Nigeria. Finally, we advocate more inclusive and interpretive research for greater understanding of the issues to offer useful data for policymaking and decision-making on the perspectives of preparing graduates for work.
\end{abstract}

Keywords: Graduate Employability, Higher Education, Labour Market, Generic Skills

\section{Introduction}

Higher education system (HES) across the world has gone through many transformations over the years (Bagwasi, 2019; Bordoloi, 2018; Hawkins, 2008; Masino \& Niño-Zarazu', 2016; Pitan, 2017). These transformations have been in response to the changing social and economic status (Auld and Morris, 2019; Bagwasi, 2019). Despite the changes, there are still criticisms that HES are failing to produce graduates who can be relied upon to integrate the functions of management (e.g. Álvarez-González, López-Miguens, Caballero, 2017; Leong, 2013; Millar \& Price, 2018). It is believed that students should have a broad base of pedagogical content knowledge, critical thinking, communication, (Carvalho and Yeoman, 2018; Guilherme \& de Freitas, 2017; Shih, 2019; Sojot, 2018); problem-solving, and team working ability (Alt, 2015; Bjørnsrud \& Engh, 2012; Garnjost and Brown, 2018) which are the aims of modern higher education. Arguably, many of these pedagogical contents are lacking in the Nigerian higher education (HE). Since the development of university education in Nigeria, more and more attention has been given to theoretical content knowledge development while the practice of holistic and competency 
education is often ignored (Okolie, Igwe \& Elom, 2018; Okolie, Nwosu and Mlanga, 2019). As a result, students attain 'theoretical content knowledge' ability, but lack professionalism and generic skills (Bagwasi, 2019; Hassan, et al., 2015; Okunuga and Ajeyalemi, 2018). This might lead to graduates overestimating their capability, performance, or chances of success (Bi et al., 2016; Johnson \& Fowler, 2011; Anderson et al., 2012). It is reasonable to expect that this should play a major role in the behaviours expected based on an individual's cognitive status (Herz, Schunk, \& Zehnder, 2014; O’Leary, 2017; Tomlinson, M. 2007).

Enhancing graduate employability is a priority for many stakeholders in higher education (O'Leary, 2017), and this study explores HE stakeholders' experiences of, and attitudes towards, the inclusion of employability-related support in undergraduate degree programmes. The embedment of soft skills into HES is closely related to the curriculum philosophy brought by the respective institutions (Hassan et al., 2015). Nowadays, employers are increasingly demanding a greater range of high-level of skills such as effective communication, team working, problemsolving, specific to the need of the labour market (Evans et al., 2012; Jackson, 2012; Mattern, 2016). However, there is a continuing disparity between industry expectations and higher education provision (Jackson, 2012). It is recommended that educationalists, policy makers and government departments need to pay greater attention to generic skills and should focus less on transferable and core skills if the impact of graduates on the industry is to be more effective (McLarty, 2005). Indeed, sustainable education is what is needed to promote employment, earnings, health, and poverty reduction in the society. The Organisation for Economic Cooperation and Development Learning Framework 2030 (OECD, 2018) explains that the future of education and skills and 'education quality' should encompass the non-cognitive dimensions highlighted in SDG 4.7:

...the knowledge and skills needed to promote sustainable development, including, among others through education for sustainable development and sustainable lifestyles, human rights, gender equality, promotion of a culture of peace and non-violence, global citizenship and appreciation of cultural diversity and of culture's contribution to sustainable development. (Target 4.7, United Nations Educational, Scientific and Cultural Organization (UNESCO, 2016: 20); cited in Auld \& Morris, 2019, p. 2-3).

In this study, the focus is on the teaching of generic skills in the Nigerian HEIs. Arguably, Nigerian HES like many developing countries, have inadequate and ineffective policies aimed at directing changes in behaviour or cognitive processes (see, e.g. Darvas, et al., 2017; Varghese, 2016). It is no longer enough for graduates to have a good degree, but they should also possess the skills and attributes required to contribute to the world of work and economy (Rata, 2017; Pitan, 2016). This led us to explore some thought-provoking research questions.

- RQ1. How do HEIs in Nigeria conceptualize generic skills in their pedagogical teaching and learning?

- RQ2. Why do HEIs have problems with teaching generic skills in its graduate programmes? 
By applying a qualitative approach through interviewing and exploring these questions, we hope that our study will contribute to 'missing paradigm' in research towards teaching generic skills in Nigerian HE. Finally, we hope that the findings will enable us to develop implications and recommendations for policy, practice and society. This study is timely, given that one of the major issues seeking urgent attention is complaints from the industries and businesses over the poor quality of current graduates in the developing countries (Bandele and Faremi, 2012). In this regard, several studies have reported that the majority of the HE graduates are not employable due to poor skills (e.g. see Hansen and Haaland, 2015; Umar, Audu and Idris, 2009).

\section{Generic Skills}

Generic skills which are also referred to as key skills or core competencies are significantly used in the present conversations in society, working life and education (Virtanen and Tynjälä, 2018). The OECD at the beginning of the millennium initiated the definition and selection of key competencies, which defined the key competencies that every citizen requires to achieve a wellfunctional society (Katajavuori, Lindblom-Ylänne, and Hirvonen, 2006). In Europe for instance, there is an inclusion of the generic skills in the national and international qualification frameworks, for example, the European Qualifications Framework, which facilitates the students' knowledge (European Qualifications Framework, 2008). Australia, for instance, created a centralized generic skills assessment tool which they call the Graduate Skills Assessment (Hambur, Rowe and Luc, 2002). There are other examples like the Cambridge Thinking Skills Assessment in the UK (TSA Cambridge, 2008) as well as the Work Keys System assessment conducted by the American College Testing Center for Education and Work (Saterfiel and McLarty, 1995).

Virtanen and Tynjälä (2018) maintain that several business leaders and educators have developed some models and listed some skills which they referred to as 'twenty-first skills' that the students require in their lives and work to ensure that they are successful in the world of work. Generic skills have also been emphasized in the assessments and comparisons of education systems with a view to enhancing the quality of teaching and learning and graduates' outcome (Coates and Richardson, 2011). There are several forecasts that the labour market will lay more emphasis on generic skills in the future (see e.g. Forbes, 2013; Future Work Skills 2020, 2011), and the current researches from various fields have shown that in addition to the job-related requirements such as the field-specific (technical/professional) skills, that the employers need, they also require the generic skills (communication, critical thinking, problem-solving, teamwork, lifelong learning, professional ethics, entrepreneurship, leadership, etc.) (Okunuga and Ajeyalemi, 2018; Virtanen, Tynjälä, and Collin, 2009). This corroborates the McClelland (1973)'s behavioural competencies, which are used by the companies as the basis for staff selection (See table 1).

\section{Table 1: McClelland's 20 behavioural competencies}



1. Self-control
11. Initiative
2. Self-confidence
12. Interpersonal understanding
3. Organizational commitment
13. Customer service orientation
4. Flexibility
14. Impact and Influence
5. Expertise
6. Information seeking
15. Organizational awareness
7. Analytical thinking
16. Relationship building
8. Conceptual thinking
17. Directiveness
9. Achievement motive values
10. Concern for order
18. Developing others
19. Teamwork and cooperation
20. Team leadership

Source: McClelland (1973 cited in Spencer \& Spencer (1993)

Drawing on the previous studies on how lack of generic skills negatively affects the graduate employability (Virtanen and Tynjälä, 2018; Virtanen, Tynjälä, and Collin, 2009; Yorke and Knight, 2006), a survey from a major online employment agency found that the major reasons for the graduates not getting employed by the employers are the lack of communication skills (56\%), bad social manners (36\%), requesting excessive pay packages (32\%), acquiring irrelevant qualifications (30\%), and being overly choosy about jobs (23\%) among others (Salina, Nurazariah, Noraina, and Rajadurai, 2011). In the same way, the study conducted by the Stanford Research Institute and Carnegie Melon Foundation 'involving Fortune 500 CEOs revealed that 75\% of getting and maintaining a job successfully is supported by individual's generic/soft skills, while only 25\% accounts for hard skills or technical knowledge' (Malhi, 2009: 49). These generic skills are very intangible but very crucial and relevant to the employers. Since lack of generic skills contributes to a large extent the reasons for unemployability of graduates, this study assumes contributes to the knowledge of the development of the concept and why HEIs in Nigeria are not able to teach high-level generic skills to students.

\section{Theoretical Context}

This paper adopts the 'Human Capital Theory' (HCT) proposed by Theodore Schultz in his 1960 article on "Capital Formation by Education" (Holden and Diddle, 2016; Schultz, 1960). Schultz, (1961: 1) states "I propose to treat education as an investment in man and to treat its consequences as a form of capital. Since education becomes a part of the person receiving it, I shall refer to it as human capital." Schultz was of the view that education is a key to economic growth and development in every society, based on its quality and quantity. High-quality education is highly required to achieve economic development as noted by Okolie (2014) that no nation can rise above its level of education. The HCT assumes that education is extremely instrumental and necessary to advance the productive capability of a people. The HCT argues that people that are highly educated are very productive people. The HCT lays emphasis on how quality education can increase the productivity of the labour force by improving their capabilities. As Bills and Klenow (2000) and Cohen and Soto (2007) noted, the provision of formal education is seen as an investment in human capital, which proponents of the theory have considered as equally or even more worthwhile than that of physical capital.

According to Boeteng and Ofori-Sarpong (2002:39), "this expectation is rational from the perspective of human capital theory, which explains that the main determinant of the demand for higher education is the expectation of higher earnings over an individual's lifetime, and higher income is necessary to compensate for the high costs associated with higher education". Given the 
current challenge of the high rise of graduate unemployment, increases in the dependency ratio, poverty level, social ills and delinquent behaviour and increases in recruitment costs" (Pitan, 2016), the expectations of the HCT becomes an illusion for the majority of the developing countries' graduates, especially, Nigerian graduates. Arguably, HEIs can only be considered labour market ready and HCT compliant if graduates it develops both core knowledge and competencies required by the labour market (Pitan, 2016). To achieve the aims of the HCT, the HEIs may consider introducing innovative teaching pedagogics and provision of a good learning environment that can foster the teaching of employability skills (Tomlinson, 2017) in order to achieve sustainable education. Arguably, such innovative teaching methods should involve 'active interactions and collaboration that utilizes the features of the constructivist learning environment, constant curriculum and pedagogical content evaluation (Carvalho and Yeoman, 2018) that will enable graduates to compete and collaborate in a dynamic knowledge economy (Pitan, 2016).

\section{Graduate Employability in the Nigerian Context}

Graduate employability is a global issue that has received scholarly attention (Felicetti, Morosini and Somers, 2013; Jackson, 2012; Mattern, 2016; McLarty, 2005; Rowe, 2019)), especially, since the global recession and the era of drastic increase in the emigration of tertiary-educated young people seeking further qualification and employment abroad (Tomić \& Taylor, 2018). Yorke (2006) sums up the tenets of employability as "a set of skills, knowledge and personal attributes that make an individual more likely to secure and be successful in their chosen occupation(s) to the benefit of themselves, the workforce, the community, and the economy" (p.21). This proves that there is a lot of importance attached to issues related to graduate employability and how to alleviate the situation of graduate unemployability in the developing world, especially Nigeria due to skills gap (Oladokun and Olaleye, 2018). In Nigeria, evidence from previous researches showed that there is a high rate of graduate unemployment, which is not related to lack of jobs (see e.g. Emeh, Nwanguma and Abaroh, 2012; Oladokun and Gbadegesin, 2017; Oladokun and Olaleye, 2018; Pitan, 2010; 2015; 2016), rather due to lack the employable skills that the labour market (employers) needs (Geo-Jaja and Mangum, 2003; Okunuga, and Ajeyalemi, 2018), and due to skill gap and mismatch (Oladokun and Olaleye, 2018; Pitan, 2017).

To further explain the graduate employability situation in Nigeria, Emeh et al., (2012) found that out of about 40 million unemployed youths in Nigeria, 23 million were unemployed due to lack of employable skills, and the majority are university graduates. To support this claim, Mahmood (2014), the Central Bank of Nigeria noted that over $70 \%$ of the unemployed youths in Nigeria lack the right skills required by the labour markets, and the majority are the HE graduates. Consequently, many employers have raised serious concerns over the skills possessed by their employees (Akanmu, 2011). As revealed by previous studies, some of the employability skills lacked by the Nigerian HE graduates include but not limited to communication, information technology, decision-making, critical thinking, interpersonal relationship, technical and numeracy skills. These findings demonstrate the need for urgent actions by HE policy makers and HEIs to ensure that thousands of graduates produced yearly in Nigeria possess technical skills and the generic skills required by today's industry and labour market. Hence, the importance of this study.

\section{Methodology}


This study draws on in-depth interviews which were conducted in three phases. The first phase is the interview with the final year undergraduate students in one of the oldest federal universities in Nigeria. The students came from the Faculties of Sciences, Education, Engineering, Medical Sciences, Management and Social Sciences, and Arts and Humanities. In line with ethical procedure of the university, some students were approached and request for volunteers to participate in the study interviews. Volunteers were requested to complete an expression of interest forms, sign and email to the researcher as a piece of evidence that they consent to participate in the interviews. The students were also informed that they will be required to explain their university experiences with an emphasis on the issues related to learning approaches and generic skills acquisition (Chan 2010). There were trained research assistants who assisted in conducting the study. After three weeks, 57 students returned the completed expression of interest forms indicating their interest to participate in the interview. Through purposeful sampling (Denzin and Lincoln 2005), 27 respondents were selected and interviewed. The 27 respondents include 12 males and 15 females between the ages of 22 to 25 years.

The second phase was the interview with the industry executives linked to the HEIs. Email invitations were sent to 62 experts in the various field. The invitation letters made clear the aim of the study and requested a short biography of interested participants. They were also asked to email the researcher their acceptance to participate in the study. The process had a response rate of 39 respondents. Again, through purposeful sampling (Denzin and Lincoln 2005), 23 individuals with $10-15$ years of experience in the industry were selected and interviewed. The third phase was the interview with the Academics. Email invitations were sent to the 82 professors with the aim of the study made very clear, asking for volunteers to participate in the study. Their short biographies were requested to ensure that they are 'information rich' to offer their views on the subject of the study based on their years of teaching experiences in the HEIs. They were instructed to contact the researcher with the completed expression of interest form. Out of the 82 contacted, 41 expressed their willingness to participate in the study. Through purposeful sampling, 22 with experiences ranging from $10-20$ years were selected for interviews.

\section{How data was collected and analyzed}

The industry executives and the university professors were not in the same location, the researcher with the help of trained research assistants used telephone calls, WhatsApp calls and face-to-face methods to conduct the interviews. The process allowed us the opportunity to question and further explore deeper into the issues relating to the graduate employability. The students were in the same location, and they were interviewed face-to-face. In addition, one focus group comprising of seven (7) students of the 27 selected respondents was conducted._Having considered the literature review and theoretical position, it was decided to use a qualitative research method and employ triangulation to enhance validity and reliability (Rolfe 2006). Ary, Jacobs, and Sorenson (2010) explained that the qualitative research methods enable the capture of a rich and comprehensive image of a situation and allow the participants to share their views about their experiences in detail. Data was collected using a semi-structured interview approach (Wengraf 2001). Focus group interview was used to validate responses from the face-to-face interviews and to explore more indepth the themes that emerged from the interviews (Creswell 2007; Igwe et al., 2018a \& b). The interviews with the three groups lasted between 45 minutes to 120 minutes. 
The number of the respondents were believed to be adequate for the study since previous studies, for instance, Griggs et al. (2018) based their study on 18 HR professionals to investigate reflective practice skills on a professional course. The interviews were recorded and transcribed verbatim and analyzed using thematic analysis approach where the key research questions served in identifying the interesting contexts of the discussion (Guest, MacQueen and Namey, 2012). To facilitate the analysis, data analysis package (NVivo), was used to identify and explore concepts and themes, trying to ascertain the best explanation for the relationship under study (Guest, MacQueen and Namey 2012). In all, the participants of the study proved that they have an in-depth understanding of the issue under study except some students who had some hard times understanding the concept of generic skills. However, the findings of the study provide rich information to guide our understanding of conceptualization of generic skills and why HEIs in Nigeria are not able to teach generic skills to students - the focus of this study.

\section{Findings}

The importance of teaching generic skills and the inclusion of employability-related support in undergraduate degree programmes have been publicized in many contexts (Anderson, Culkin, Penaluna, and Smith. 2014; O'Leary, 2017; Tomlinson, M. 2007). These studies which provide the background to our study, emphasises the need for HE to focus their attention on graduate employability and how to change student attitudes and orientations to the Labour Market. In this study, we have adapted thematic analysis to facilitate the identification of the key themes which formed the basis of our findings and discussion in line with the research questions and objectives which include; (1) How do HEIs in Nigeria conceptualize generic skills in their teaching (including the perceptions teachers and students)? (2) Why do HEIs have problems teaching generic skills to students? These questions were explored, and the findings presented in this section.

\section{Teaching Generic Skills in HE}

The teaching of generic skills in the HEIs and in the workplace has been investigated by several studies (Evans, et al., 2012; Jackson, 2012; O’Leary, 2017). For example, Crebert et al. (2004) revealed that $80 \%$ of graduates learned generic skills in equal proportions in university and in working life. Their study further revealed that the best and easier way to acquire generic skills in the HEIs is to join different group activities, while in the work-life context, the best way is to successfully work with other staff. Other studies revealed that to learn generic skills, it is important that the individual is in the constant practice of interacting with others and be in activities as well with others (de la Harbe, Radloff, and Wyber, 2000). According to Moy (1999), collaborative rather than individual learning promotes generic skills. 'Other important approaches such as social, interactive and collaborative characteristics of students' experiences of HE life reveal significant determinants of generic graduate outcomes' (Smith and Bath, 2006: 271).

Evidence from many studies in developed countries suggests that HEIs, educationalists, policymakers and government departments pay greater attention to generic skills (Jackson, 2012; Mattern, 2016; McLarty, 2005; Sojot, 2018). Arguably, HEIs in Nigeria, like many African countries put more emphasis on 'content knowledge' (Okolie, Nwosu and Mlanga, 2019) and less emphasis on generic and softer skills (Pitan, 2017; Okunuga and Ajeyalemi, 2018) and this has been regarded as a disadvantage (Bagwasi, 2019; Darvas, et al., 2017; Varghese, 2016) leading to a high rate of graduate unemployment. To explore the question; how do HEIs conceptualize the teaching of generic skills, we present the views of students, senior academics and industry experts. 


\section{Views on the Conceptualization of Generic Skills in the HEIs}

During the interviews and focus group meeting with final year students, they had some difficulties understanding the exact meaning of generic skills such as Lifelong learning skills, interpersonal skills, leadership skills, integrity and professional ethics skills, and information management skills among others. They showed that they have a good understanding of some generic skills such as creative and critical thinking skills, negotiation skill and teamwork skills, but they openly admitted that they are not aware if they possess any of the skills. Here is an excerpt from one of the participants;

[...] I can't explain if I have any of those skills you mentioned but I do know that I am entrepreneurial oriented, and I have good writing and communication skills. I can work with colleagues but am not sure if I have been taught the relevant leadership, IT and professional skills required to succeed in the society (Participant 4: Final Year University Student).

It is evident from interviewing students and senior academics that HEIs focuses more on exploring theoretical concepts and teaching skills such as writing, communication and listening skills. However, other important skills have not been adequately incorporated in the curriculum and learning activities. This is typical of HES in Nigeria where students are poorly taught, and curriculum underdeveloped (Havergal, 2015). Some of the academics interviewed believe that the current HES is not working in favour of graduate experience and quality, hence, HE policies and curriculum need to be re-validated to be fit for purpose. Many of the students believed that from personal assessment that they possess some of the generic skills like communication skills, but many admitted to lacking other generic skills such as emotional mastery resourcefulness, skills related to problem-solving, critical thinking, leadership skills, interpersonal skills, professional ethics skills, IT, information management skills, etc. Therefore, HE graduates in Nigeria are poorly prepared for the labour market (Hanushek et al., 2017) and entrepreneurship (Anderson et al., 2014). One of the academic participants, therefore, suggests that there is a need for the HEIs to offer the teachers with adequate training to enable them to understand how to teach generic skills; [....] I think the idea of imparting the students with the generic skills is not new in the higher education institutions, but the issue is that the system needs total rearrangement to ensure quality assurance. The lecturers need to be adequately trained to possess these skills first before imparting such skills to the students (Participant 2: University Professor).

From an industry perspective, the lack of knowledge of generic skills among new graduates is worrisome and posse's danger for the future of the workforce. Some of the industry experts pointed out that the majority of the graduates lack high-level generic skills such as communication, collaboration, innovation, creativity, and critical thinking. These skills have been highly neglected by the Nigerian HEIs (Okunuga and Ajeyalemi, 2018; Okolie, Igwe and Elom, 2018). Some of the industry experts suggest that the HEIs should devote more time teaching generic skills to students to enable young people to contribute to the economy by creating a more entrepreneurial mindset and professional individuals;

As a managing director, I have personally rejected several graduates due to that they have poor communication, leadership, and critical thinking skills. While we need these skills, I 
noticed that they lack in excess in the fresh graduates who often come for job search (Participant G: Industry Expert).

It worth pointing out that the magnitude of the problem created by lack of generic skills among new graduates is not only unique to Nigeria but a global issue (see, e.g. Álvarez-González, LópezMiguens and Caballero, G. 2017; Hassan et al., 2015; Tomlinson, 2007). However, given the high rate of graduate unemployment in Nigeria and many other African countries, the impact is more felt in the African region than other regions (Bagwasi, 2019; Darvas, et al., 2017; Havergal, 2015; Varghese, 2016). A manufacturing industry executive explained during the interview that they can go all out just to get the graduates with generic skills in addition to the main technical skills they acquired from their disciplines or courses studied in the HEIs;

[....] During a recent job interview that my company conducted, we received over four thousand applicants. After the initial screening, we selected about 80 graduates who qualified for the second round of the interviews. During the week-long recruitment exercise, I found that the universities have not done much in equipping their graduates with the generic skill which we seriously look out for in the graduates. My reason for this statement is because, while the 80 second round applicants possessed the technical skills, we had challenges selecting up to 20 applicants among them who possess other important skills like the ability to critically think, ability to solve occupational problems and teamworking skills (Participant B: Industry Executive).

From our findings, it might be right to conclude that the current situation of lack of relevant skills among new graduates is one of the major factors causing a high rate of graduate unemployment in Nigeria. It is evident that jobs exist as revealed by some of the industry experts but lack of local qualified applicants are driving businesses to seek foreign graduates to fill the vacant positions;

[....] Sorry to sound this way...I prefer to spend heavily on recruiting foreign graduates in my company to recruit our own graduates, because, our graduates lack skills like problemsolving, information management, and integrity and professional ethics (Participant F: Industry Executive).

Evidently, the lack of generic skills affects the recruitment of new graduates. This corrects the earlier held impression that the major reason why there is a high rate of graduate unemployment is due to the scarcity of industries. This is not the case with Nigeria where many studies have reported that the economy has been booming and new firms emerging (African Economic Outlook (AEO, 2016) and Global Entrepreneurship Monitor (GEM, 2017). These studies note that the growth of small, medium and large-scale industries and organizations but there is skills gap and mismatch among potential job seekers which the HEIs have often overlooked. These views have also ben corroborate by the findings of Pitan $(2016$; 2017) that the major cause of graduate unemployment in Nigeria is not necessarily the lack of jobs, rather lack of the generic skills required by the employers.

\section{Problems Teaching generic skills in HEIs}

In a study conducted by Kember and Leung (2005) in a Hong Kong University on the correlation between students' experiences of learning generic skills and the learning environment, they found that 'teaching for understanding, active learning, a variety of assessment methods that require the 
deployment of the desired capabilities and working together' were the characteristics of the learning environment that particularly develop the students' generic skills (Kember, Leung, and $\mathrm{Ma}, 2007)$. These teaching and learning features according to Virtanen and Tynjälä (2018) are directly related to the characteristics of constructivist learning environment (e.g. Loyens and Gijbels, 2008), which is a model of integrative pedagogy that connects the features of the constructivist teaching and learning with the accounts of the nature and the development of expertise (Eraut, 2004; Virtanen and Tynjälä, 2018).

Nigeria like in many African countries, HEIs are struggling to develop appropriate HE framework that will align to international standards (Asaaju, 2015; Okolie, Nwosu and Mlanga, 2019; Okunuga and Ajeyalemi, 2018). These studies maintain that it is no longer enough for graduates to have a good degree, but they should also possess the skills and attributes required to compete and collaborate in a dynamic knowledge economy (Pitan, 2016). University roles include design, implementation and evaluation of various levels of knowledge content (Carvalho and Yeoman, 2018) and engagement in research, scholarship and collaboration with industry and government (Etzkowitz, 2017) to deliver high benefits to students. Turning to the questions - why do HEIs have problems teaching generic skills in Nigeria, we present the views of students, senior academics and industry experts.

\section{View on the problems of teaching generic skills}

The findings from this study suggest that one of the main reasons why HEIs encounter is the lack of pedagogical knowledge content on how to teach generic skills. These have been attributed to many factors and challenges including the lack of trained academics and professionals with good knowledge and industrial background. As noted by several participants, many academics working in the HES do not have industrial experience and the majority has been recruited on the basis that they possess PhD qualification (Okolie, Nwosu and Mlanga, 2019) which is a key requirement to becoming a teacher in the Nigerian HE. As a result, university teachers do not understand work or industrial needs and how to teach it.

[....] I think, our higher education institutions do not have the knowledge and have not properly understood what the industries are looking from new graduates in terms of a balance between knowledge, competencies and skills (Participant D: Industry Expert).

Another problem has been attributed to teaching and learning pedagogy adopted in the Nigerian HE (Okolie, Nwosu and Mlanga, 2019; Okunuga and Ajeyalemi, 2018; Rowe, 2019). The findings of this study show that teaching the students generic skills cannot be achieved through a single method of teaching, which is commonly used in many developing countries' HEIs. Many of the participants were of the views that majority of the HEIs predominantly use the traditional teaching methods, which only allow the students to sit, listen to the teacher who acts as the transferor of knowledge to them while the students copy the teaching notes. The study participants criticized the traditional teaching method;

[....] I personally do not believe that the students can possibly acquire the generic skills through the traditional teaching method that is predominantly in use in the higher education institutions. I call it a passive method because it does not even allow the students to effectively acquire the technical skills to talk about generic skills (Participant 6: Industry Expert). 
Some of the study participants recommended the use of active learning and effective teaching methods (Felicetti, Morosini and Somers, 2013) that can assist the students to learn through collaborations, teamwork, problem-solving, effective interaction and discussion, which can foster the learning of the generic skills (In line with findings from previous studies, e.g., Shih, 2019; Sojot, 2018; Alt, 2015; Bjørnsrud \& Engh, 2012; Garnjost and Brown, 2018) which should be the foundation of modern higher education.

Most of the universities are struggling to align their curriculum to theory and practicebased learning. If this situation persists, graduates may never learn generic skills required by the industries (Participant 10: University professor).

There seems to be a consensus agreement among the respondents that the students should be given the chances to socialize and interact among themselves and with their teachers as well as the supervisors to be able to learn the generic skills in the HEIs. The views of the participants are in agreement with those of the earlier studies (e.g. Crebert et al. 2004; Kember 2009; Smith and Bath 2006), that a single method of teaching or pedagogical practice is not adequate and hence, cannot guarantee the learning of generic skills required by the labour market. A major challenge as pointed out by some of the participants is that there is a dissonance between the skills required by the labour market and what the HEIs offer the students in Nigerian HE;

[...] I feel that there is a disconnect between what the higher education offers and what the industries require from the graduates. HE policies and programmes need to change or reflect on how to address this challenge (Participant 6: Final Year Student).

The participants' views corroborate the findings of Singh, Hambusamy, and Ramly $(2014 ; 332)$ that 'the students are losing out as the important skills are being side-tracked in favour of those skills that are more geared to teaching and assessment. It is indeed a startling revelation and one that should be taken seriously by the higher education policymakers.' Another challenge pointed out by the participants includes the teaching methods, poor training of the lecturers, poor curriculum development, poor interaction between the lecturers and the students, poor teaching and learning environment which negatively affect the students' development of the generic skills. In a similar study conducted by Okunuga and Ajeyalemi (2018) on Nigerian university chemistry curriculum to ascertain whether the graduates meet the minimum skills requirements by the chemistry-based industries, they found that "while the university chemistry curriculum is adequate in that it meets the minimal knowledge requirements of chemical-based industries, however, it does not meet the skills requirements.

Of course, teaching skills in HE will involve collaboration, small group discussions, problemsolving and interaction, as well as strong HEIs' relationship with the industries and labour organizations. There have been calls from company executives, international organisations and policymakers for HEIs, industry and labour to further collaborate and maximize the quality support and teaching in the HE (Cunningham et al. 2018; Etzkowitz, 2017). This position has been strengthened by views of some of this study participant who advocate for collaborative and partnership initiatives towards solving graduate employability challenges;

[...] I think that the students can learn generic skills if they are offered the chances of learning through industrial placements or internship programs which should be supervised by teachers and the industry supervisors (Participant 7: Industry Executive). 
[...] Generic skills cannot be taught through HEIs working alone rather the best result will be through collaboration and partnership (Participant 13: Industry Executive).

These findings corroborate evidence from previous studies such as Virtanen \& Tynjälä (2018, p. 10) that 'the pedagogical practices that predicted students' learning of generic skills most strongly were those that belonged to the constructivist learning environment features (i.e. critical examination of knowledge; sharing and utilizing students' earlier experiences and knowledge; and feedback, assessment and summarizing tasks) along with the interactive pedagogy features (i.e. acting at the interface between theory and practice)'. Also, the present study found that good learning environment plays a significant role in fostering the students learning of generic skills in the HEIs. The benefits of learning of generic skills to the graduates as pointed out by the study participants are enormous. They include but not limited to the development of personal values, attitudes, attributes, ethics and integrity, confidence and self-esteem, respecting the ideas and opinions of others, respecting diversity, initiative, and creativity, reliability and responsibility. Hence, through teaching generic skills, graduates are better prepared for employment.

\section{Discussion, Conclusion and Implications}

This study has presented the findings on how the learning of generic skills can be enhanced to foster graduate's employability. It has also presented the findings based on the views of students, senior academics and some industry experts. The main findings of this study suggest there is still much to do to offer HE graduates in Nigeria the right support they so desperately need to help them compete, gain employment and thrive in the society, rather than just survive. Evidence is emerging to suggest that compulsory enterprise activities in schools could impact on later engagement in Further and Higher Education (Anderson, Culkin, Penaluna, and Smith. 2014). In their study, Anderson et al. (2014) posit that the wrong type of education, such as where students talk about the enterprise as opposed to actively engaging and developing their skills, may have negative results. As we stated earlier, this might lead to graduates overestimating their capability and chances of success (Bi et al., 2016; Johnson \& Fowler, 2011) and could play a major role in the forming behaviours (Herz, Schunk, \& Zehnder, 2014).

In the developing countries like Nigeria, adequate measures are not in place in HEIs to teach generic skills and this could be one of the reasons for the persistent trend of graduate unemployment (Álvarez-González, López-Miguens, Caballero, 2017). Our findings reveal that HE programmes and curriculum are missing the vital paradigms linked to sustainable education. As noted earlier, the embedment of soft skills into HES (Hassan et al., 2015) will enable graduates to develop specific skills required by the labour market (Evans et al., 2012; Jackson, 2012; Mattern, 2016). Therefore, if the dissonance between the HEIs programmes and the demands of the labour market is not paid attention towards through overhauling of the HE system, the problem of graduates' unemployability may continue to be on the increase. In response to graduate unemployment in Nigeria, entrepreneurship education was introduced into the HES to enable students to acquire entrepreneurial skills. Arguably, this action is not enough, as such extension of entrepreneurship curriculum is required at the primary and secondary levels. More HE policymakers and administrators need to find ways to overcome the challenges or barriers to teaching generic skills and practice-based learning. The following improvements are required in relation to teaching methods, adequate continuous professional development and training of HE 
staffs, curriculum development, improved funding and learning environment. It is expected that such measures will enable HEIs to develop the capacity and competencies required to deliver inclusive learning required to achieve sustainable education (OECD, 2018; UNESCO, 2016).

Regarding implications for social, practice and policy, the importance of the 'pedagogical content' elements of the HE (Carvalho and Yeoman, 2018) is evident. Linked to Human Capital Theory (HCT), there is a need to build a stronger link between content learning, competencies and development of softer skills to ensure graduates generate knowledge and skills required in order to pursue 'education for social development and cognitive processes (see, e.g. Darvas, et al., 2017; Varghese, 2016). This is an important dimension, given the calls for HES in developing countries to transform and develop young generation by reorienting education policies (Darvas et al., 2017; Felicetti, Morosini and Somers, 2013 Tomić and Taylor, 2018). In light of the situation and linked to our findings, we make some recommendations. First, we advocate a re-validation of HE curriculum to align it to international standards that encourage, class-based activities, outdoor activities, self-directed learning, teamworking, problem-solving and critical thinking. To overcome the present challenges will require innovative redesigning of programmes, teaching methods, assessments and other activities of HE (see, e.g. Cunningham et al., 2017; Etzkowitz, 2017). Second, we recommend enterprise education to be mandatory in the curriculum for primary, secondary and tertiary institutions in the Nigerian education system. Such an approach will align with international standards. In their report on education system fit for an entrepreneur by the AllParty Parliamentary Group for Micro Businesses developed by Anderson, Culkin, Penaluna, and Smith (2014) they recommended enterprise education to be mandatory for 4 to 18 -year olds, with the Government having an overarching strategy across departments on enterprise education. Following the recommendation by Anderson et al. (2014) we propose that enterprise education needs to be offered across all courses and levels of tertiary education to improve the number and quality of business start- ups and quality labour force. Third, we advocate the promotion of effective stakeholders' partnership involving Nigerian HEIs, industry, labour and government, each contributing according to its 'institutional' function in society (McAdam, Miller \& McAdam, 2017). Such an approach will enable HEIs to develop robust practice-based learning, placements and internship programmes and as well as to advanced research and scholarship. To facilitate this, current Government support needs to be re- evaluated, and engagement between education and the SME sector needs to be increased and incentivized (Anderson et al., 2014).

Finally, our study makes an important contribution to the knowledge of HES in Nigeria. One of the greatest barriers facing African countries is, in fact, one of robust research and evidence on which to base policy (British Council, 2014, p. 7). Our study has relied on a qualitative method that enabled us to explore the views of students, senior academics and industry-experts - this is one of the strengths of this research. By interviewing 72 participants, the method enables participants to share their views and contribute to guiding our understanding of conceptualization of generic skills and why HEIs in Nigeria are not able to teach generic skills to students - the aim of this study. Despite the robust method and validation process adapted, like many qualitative types of research, there are some limitations related to the size of the data, scope and reliability. Overall, this study provides a foundation for future studies in Nigeria. One opportunity is to examine the experiences, trends and generational attitudes to graduate employability, including appraisals of the impact of different higher education policies over the years (O'Leary, 2017), through a quantitative approach. Such a quantitative study could be carried out with a larger sample. 


\section{References}

Akanmu O (2011) Graduate employment and employability challenges in Nigeria. Paper presented at the British Council Global Higher Education Conference, Hong-Kong, March 12,2011

Ary D. Jacobs, L. C. and Sorenson C (2010) Introduction to Research in Education." New York: Wadsworth Cengage Learning.

Ayonmike S C (2008) Skill training in Nigerian technical colleges: Benefits and challenges". Journal of Qualitative Education 6 (1): 185-187

Bandele S O and Y A Faremi (2012) An investigation into the challenges facing the implementation of the technical college curriculum in South West Nigeria. Journal of Education and Practice 3(16): 14-20

Bills M and Klenow P (2000) Does schooling cause growth? American Economic Review, 90(5): 1160-1183.

Boateng K and Ofori-Sarpong E (2002) An analytical study of the labour market for tertiary graduates in Ghana. World Bank/National Council for Tertiary Education and the National Accreditation Board Project, Accra, Ghana.

Callan V (2003) Understanding vocational education and training teacher and student attitudes. NCVER, Adelaide.

Chan W S C (2010) Students' understanding of generic skills development in a university in Hong Kong. Procedia Social and Behavioral Sciences 2: 4815-4819.

Coates H and Richardson S (2011) An International Assessment of Bachelor Degree Graduates' Learning Outcomes. Higher Education Management and Policy 23 (3): 52-69.

Cohen D and Soto M (2007) Growth and human capital: Good data, good results. Journal of Economic Growth 1(3): 113-207.

Crebert G M, Bates B, Bell C, Patrick J and Cragnolini V (2004) Developing generic skills at university, during work placement and in employment: graduates' perceptions Higher Education Research \& Development 23 (2): 147-165.

Creswell J W (2007) Qualitative inquiry and research design: choosing among five approaches. 2nd Ed. Thousand Oaks: CA: Sage.

Dabalen A, Oni B, and Adekola, OA (2001) Labor market prospects for university graduates in Nigeria. Higher Education Policy 14(2): 141-159. DOI: http://dx.doi.org/10.1057/palgrave. hep.83 90176.

de la Harbe B, Radloff A and Wyber J (2000) Quality and Generic (Professional) Skills." Quality in Higher Education 6 (3): 231-243.

Denzin N K and Lincoln Y S (2005) Collecting and interpreting qualitative materials. Thousand Oaks, CA: SAGE Publications USA

Griggs V, Holden, R, Lawless A and Rae J (2018) From reflective learning to reflective practice: assessing transfer. Studies in Higher Education 43 (7), 1172-1183, DOI: 10.1080/03075079.2016.1232382

Guest G, MacQueen K and Namey F (2012). Applied Thematic Analysis. London: Sage Publication. The United Kingdom.

Guerrero L and Floyd K (2006) Nonverbal Communication in Close Relationships. Mahwah, N.J: Lawrence Erlbaum. 
Hesketh A J (2000) Recruiting an elite? Employers' perceptions of graduate education and training. Journal of Education and Work 13 (3): 245-271.

Hinchliffe G (2002) Situating skills. Journal of Philosophy of Education 36 (2): 187-205.

Holden L and Diddle J (2016) The Introduction of Human Capital Theory into Education Policy in the United States. Michigan State University, USA.

Holmes L (2001) Reconsidering graduate employability: the Graduate Identity approach. Quality in Higher Education 7 (2): 111-119.

Emeh I E, Nwanguma EO, and Abaroh J J (2012) Engaging youth unemployment in Nigeria with youth development and empowerment programmes: The Lagos state in focus. Interdisciplinary Journal of Contemporary Research in Business 4: 1125-1141.

Eteläpelto A and Lahti J (2008) The Resources and Obstacles of Creative Collaboration in a Longterm Learning Community. Thinking Skills and Creativity 3 (3): 226-240.

EQF (2008). European Qualifications Framework. Accessed June 9, 2016. http://ec.europa.eu/education/lifelong-learning-policy/eqf_en.htm.

Eraut M (2004) Transfer of knowledge between education and workplace settings. in workplace learning in context, edited by H. Rainbird, A. Fuller, and A. Munro, 201-221. London: Routledge.

Forbes (2013) The 10 skills that will get you hired in 2013. Assessed April 10, 2017. http://www.forbes.com/sites/meghancasserly/2012/12/10/the-10-skills-that-will-get-youa-job-in-2013/\#57b60d9664b0.

Future work skills 2020. 2011. Assessed April 10, (2017) http://www.iftf.org/uploads/media/SR1382A_UPRI_future_work_skills_sm.pdf.

Hansen K and Haaland G (2015). Utfordringer I Norsk yrkesoppl_ring. [Challenges in Norwegian vocational education]. In Hansen, K., L_kensgard-Hoel, T. \& Haaland, G. (Eds.). Tett p_a yrkesoppl_ring [Close to vocational education]. Bergen: Fagbokforlaget, 19-49.

Hambur S, Rowe K and Luc LT (2002) Graduate skills assessment: Stage one validity. Canberra: Australian Council for Educational Research.

Katajavuori N, Lindblom-Ylänne S and Hirvonen J (2006) The significance of practical training in linking theoretical studies with practice. Higher Education 51(3): 439-464.

Kember D and Leung DYP (2005) The Influence of Active Learning Experiences on the Development of Graduate Capabilities. Studies in Higher Education 30 (2): 155-170.

Kember D, Leung DYP and Ma RSF (2007) Characterizing learning environments capable of nurturing generic capabilities in higher education. Research in Higher Education 48 (5): 609-632.

Loyens SMM and Gijbels D (2008) Constructivist Learning Environments: Introducing Multidirectional Approach. Instructional Science 36 (5-6): 351-357.

McClelland D (1973) Testing for competence rather than intelligence. American Psychologist 28: $1-14$.

Malhi R S (2009) The hard truth about graduate employability and soft skills. ADEPT: Higher Education Leadership Research Bulletin 3: 45-56.

Mark van V, Menno DT and Erwin RS 2007) Direct and indirect effects of supervisor communication on organizational commitment. Corporate Communications: An International Journal 12(2): 116-128.

Morley L (2001) Producing new workers: quality, equality and employability in higher education. Quality in Higher Education 7 (2): 131-138. 
Moy J (1999) The impact of generic competencies on workplace performance. Review of Research, National Centre for Vocational Education Research (NCVER).

National Universities Commission (NUC) (2004) Report of national needs assessment surveys: labour market expectations of Nigerian graduates. National University Commission (NUC), Abuja, Nigeria.

Nik Hairi O, A. M., Azmi, H. M., Rusyda, C. K. Arena, and A. A. Khairani. 2012. "Employability skills based on current job demand through electronic advertisement." Asian Social Science. 8 (9): 103-110.

Okolie UC, Igwe PA and Elom EN (2018) Improving graduate outcomes for technical colleges in Nigeria. Australian Journal of Career Development, [...] pp. 1-20 DOI:10.1177/1038416218772189 Accepted 30 April 2018. [In press]

Okolie UC and Asfa M Y (2017) Human development and TVET dimensions In Okolie, U. C. and Asfa, M. Y. (Ed.). Technical Education and Vocational Training in Developing Nations. Hershey, USA. IGI-Global International Publishers.

Okolie UC (2014) Management of woodwork workshop in tertiary institutions in Nigeria: an analytical study. Malaysian Online Journal of Education 2 (1): 20-36.

Okunuga R O and Ajeyalemi D (2018) Relationship between knowledge and skills in the Nigerian undergraduate chemistry curriculum and graduate employability in chemical-based industries. Industry and Higher Education, 32, (3), 183-191, https://doi.org/10.1177/0950422218766913

Oladokun S O and Gbadegesin J T (2017). Adequacy of core knowledge and soft skills in the performance of professional employees of real estate firms in Nigeria. Property Management, $\quad 35, \quad$ (2), 132-149. https://doi.org/10.1108/PM-02-2016-0008

Oladokun T T and Olaleye A (2018) Bridging skill gap in real estate education in Nigeria. Pacific Rim Property Research Journal 24, (1), 17-34, https://doi.org/10.1080/14445921.2017.1409153

Phillips Consulting (2014) Education and Employability Survey Report. From www.phillipsconsulting.net. (Retrieved on 20 January 2015).

Pierce D (2002) Employability: higher education and careers services. Abridged version of a report prepared for AGCAS (mimeo).

Pitan O S (2017) Graduate employees' generic skills and training needs. Higher Education, Skills and Work-Based Learning 7 (3): 290-303, https://doi.org/10.1108/HESWBL-04-2017$\underline{0026}$

Pitan OS (2015) An assessment of generic skills demand in five sectors of the Nigerian labour market. Public and Municipal Finance 4(1): 28-36.

Pitan O S (2016) Towards enhancing university graduate employability in Nigeria", Journal of $\begin{array}{llllll}\text { Sociology and } & \text { Social } & \text { Anthropology. } & 7 & \text { (1): }\end{array}$ https://doi.org/10.1080/09766634.2016.11885696

Pitan O S and Adedeji SO (2012) Skills mismatch among university graduates in Nigeria labour market. US-China Education Review 2(1): 90-98.

Purcell K and Elias P (2002) Seven years on... Making sense of the new graduate labour market. Graduate Recruiter, 8 (October), 22-23.

Rolfe G (2006) Validity, trustworthiness and rigour: quality and the idea of qualitative research. Journal of Advanced Nursing 53 (3): 304-310 
Salina D, Nurazariah A, Noraina MS and Rajadurai J (2011) Enhancing university business curriculum using an importance-performance approach: A case study of the business management faculty of a university in Malaysia. International Journal of Educational Management 25 (6): 545 - 569

Saterfiel TH and McLarty J R (1995) Assessing employability skills. ERIC Digest. Retrieved from ERIC Digest: http://www.ericdigests.org/1996-3/assessing.htm

Singh, P., R. X., Hambusamy, and M. A. Ramly. 2014. "Fit or unfit? Perspectives of employers and university instructors of graduates' generic skills." Procedia - Social and Behavioral Sciences 123: $315-324$

Smith C and Bath D (2006) The role of the learning community in the development of discipline knowledge and generic graduate outcomes. Higher Education 51 (2): 259-286.

Spencer L and Spencer S (1993) Competence at work-models for superior performance. John Wiley \& Sons, New York.

Schultz T W (1961) Investment in human capital. The American Economic Review 51(1):1-17

Schultz TW (1960) Capital formation by education. Journal of Political Economy 68(6):571-583.

Tomlinson M (2017) Forms of graduate capital and their relationship to graduate employability", Education + Training 59 (4): 338-352. https://doi.org/10.1108/ET-05-2016-0090

TSA Cambridge Background \& Research (2008) Retrieved from Cambridge Assessment: http://www.admissionstests.cambridgeassessment.org.uk/adt/tsacambridge/research.

Umar IY, Audu R and Idris AM (2009) Public-private sector participation in education: a panacea for provision of facilities in technical colleges in Nigeria. Journal of League of Researchers in Nigeria. 10 (1): 27 - 32.

Virtanen A and Tynjälä P (2018). Factors explaining the learning of generic skills: a study of university students' experiences. Teaching in Higher Education DOI: 10.1080/13562517.2018.1515195

Virtanen A, Tynjälä P and Collin K (2009) Characteristics of workplace learning among Finnish vocational students. vocations and learning 2 (3): 153-175.

Wengraf T (2001) Qualitative Research Interviewing: Biographic Narrative and Semi-Structured Methods. London: SAGE.

Yorke M (2006) Employability in higher education: What it is - what it is not. Heslington, York, United Kingdom: The Higher Education Academy United Kingdom.

Yorke M and Knight P (2006) Embedding employability into the curriculum. York. Higher Education Academy. 